\title{
An Evaluation of Map Literacy of Social Studies Preservice Teachers
}

\author{
Bülent AKSOY* \\ Department of Turkish and Social Sciences Education, Gazi University, Ankara, Turkey \\ ORCID: 0000-0002-7181-8008
}

\begin{abstract}
Selman ABLAK
Department of Turkish and Social Sciences Education, Cumhuriyet University, Sivas, Turkey ORCID: 0000-0001-8538-1292
\end{abstract}

\begin{tabular}{l}
\hline \hline Article history \\
\hline Received: \\
08.10 .2019 \\
Received in revised form: \\
24.11 .2019 \\
Accepted: \\
26.11 .2019 \\
Key words: \\
\hline Map literacy, map usage, \\
activities with map, geography \\
interest, social studies \\
undergraduate students
\end{tabular}

This study aims to determine the level of map literacy of social studies prospective teachers. The research was carried out using the correlational survey model. "Developing Valid and Reliable Map Literacy Scale" was the data collection tool. The research was conducted on 221 social studies undergraduate students in the 20162017 academic year. Multiple linear regression analysis technique was applied for the sub-problems of the research. The findings of the research regarding the correlations between the predictive variables and the dependent variable showed a positive and moderate correlation between the students' levels of map literacy and variables such as competence in the frequency of using map, the frequency of activity by maps, and the level of interest in Geography. On the other hand, a positive and weak correlation was explored between the students' levels of map literacy and variables such as the frequency of activity with maps. The results of the partial correlations between the predictive variables and the dependent variable indicated that the students' levels of map literacy had a positive and weak relationship with the frequency of using map and the frequency of activity with maps variables. Together with that students' levels of map literacy were determined to have a positive and moderate relationship with the level of interest in Geography variable. In addition, students' levels of map literacy were found out to have a moderate and significant relationship with the frequency of using map, the frequency of activity with maps, and the level of interest in Geography variables. The results of the research demonstrated that the map activities were a moderate predictor of map literacy. For this reason, it is suggested that importance should be given to the courses and practices that will develop the students' map skills in the social studies undergraduate curriculum.

\section{Introduction}

A map can be defined as the transformation of natural or human phenomena, events, and objects (forests, rivers, settlements, trade, tourism, etc.) or issues with spatial relationships (air pollution, income distribution, precipitation rate, etc.) on the Earth or other 
celestial bodies within a certain scale, by applying a set of cartographic rules on a two or three-dimensional surface (paper, glass, computer screen, embossed surface, etc.) (www.hgk.gov.tr). The map is basically a visual description tool. The discovery of maps as a form of expression of various physical and human subjects built an interdisciplinary, strong and important link (MacEachren, 2004) among different areas of study.

Maps are widely utilized in daily life. They may be resorted to for various purposes such as transportation, touristic trips, lectures, scientific studies, navigation, location and coordinate determination, calculation of distance and field, interpretation of physical properties, spatial planning and so on (Tümertekin \& Özgüç, 2000). Maps could mean a simple photograph of geography, a scientific representation, or images of our minds as well as visual representations. Without maps, we would have had difficulty in imagining where we are or where we live. For example, how could we otherwise know that Turkey look like a rectangle and Uzbekistan is comprised of corridor-shapes? To that end it could be said that maps are an integral part of our minds, geography, social studies and other Earth sciences (Ünlü, Üçışık, \& Özey, 2002; Demiralp, 2006; Kızılçaoğlu, 2007; Koç, 2008; Koç, 2010; Sönmez, 2010; Aksoy, 2013; Koç \& Karatekin, 2015; Aksoy, Kılıçoğlu \& Ablak, 2015).

Map skills and map literacy constitute an important part of of teaching Geography and other social studies. Thusly research on the categorization of map skills is commonly observed in the relevant literature. When the literature on map skills is reviewed, the classification of McClure (1992) and Weeden (1997) is noteworthy. The classification of McClure (1992) is highly detailed listing the ability of mapping from concrete to abstract respectively; "1) Comprehension and Interpretation of Symbols, 2) Profiling Skills, 3) Navigation Skills, 4) Distance, Field and Slope Measurement Skills, 5) Position and Coordinate Determination Skills, 6) Scale Use Skills, 7) Creating Draft Map and Define Physical Properties and 8) Map Reading and Interpretation Skills". Weeden (1997) categorized the map skills as 1) Using maps, 2) Map making, 3) Map reading and 4) Map interpretation.

The concept of literacy in education has been one of the prominent themes in the literature in recent years. Literacy standards for various subjects or disciplines have been set accordingly. Literacy generally refers to being well educated in a certain field or owning wide knowledge about a certain field (McBride, 2011, cited in Çiftci \& Koç, 2016). In this vein, map literacy is among the prominent types of literacy. Map literacy is also among the 27 skills included in the social studies 2018 curriculum. Nonetheless, it is arguably challenging to come across a definition that everyone agrees with map literacy. Koç and Demir (2014) define map literacy as the ability to use maps in daily life and to comprehend maps. Map literacy consists of the steps of information, comprehension, application, analysis, synthesis, and evaluation (Clarke, 2003). Weeden (1997), who preferred the concept of "mapping skills" over "mapping literacy"; classified the mapping skills as using maps, making maps, reading and interpreting maps. Olson (1976) identified three levels of map literacy which are the comparison of individual symbol properties, recognizing the characteristics of symbol groups on the map, and using maps as a tool for structuring information in decision-making. Buckley, Muehrcke and Muehrcke (1978) describe mapping literacy as three stages of map reading, map analysis and map interpretation. In their scale that was developed to assess map literacy, Koç and Demir (2014) divided map skills into four categories: making transactions with maps, reading and interpreting maps, drawing outline maps and utilizing maps. Rautencbach, Coetzee, and Çöltekin (2017) analyzed map skills under six categories: recognizing symbols, determining direction and route, locating, measuring and predicting, calculating and explaining, as well as interpreting (Koç, Aksoy \& Çifçi, 2017). Various studies on map skills and map literacy were 
conducted (Carswell 1971; Gilmartin \& Patton 1984; Gerberve \& Wilson, 1989; Liben \& Downs, 1989; McClure, 1992; Wood, 1992; White, 1995; Weeden, 1997; Catling, 1998; Clarke, 2003; MacEachren, 2004; Wiegand, 2006; Golledge, Marsh \& Battersby, 2008; Schultz, Kerski \& Patterson, 2008; Coach, 2008; Buckley, Muehrcke \& Muehrcke, 2011; Aksoy, 2013; Koç \& Karatekin, 2016; Koç, Aksoy \& Çifçi 2017, Aksoy \& Koç, 2017). The literature also includes two studies on the development of map literacy scale (Jongwon \& Bednarz, 2012; Koç \& Demir, 2014).

\section{Aim and Significance of the Study}

This study had an attempt to determine the social studies undergraduate students' level of map literacy. In this study, the frequency of using maps, the frequency of activity with maps and the level of interest in Geography are regarded as predictive variables to explore map literacy of social studies students and the study also intended to explore the effect of these predictive variables on the level of map literacy.

The literature review shows that the studies on map literacy in social studies teaching are rather insufficient in terms of quantity and quality. Therefore, it is supposed that the current research will be a reference for the studies to be conducted on this subject in years to come. In addition, the findings may form an important source of data for practitioners and program development experts especially bearing in mind the fact that the absence of a must course on map knowledge/skills in social studies degree program in Turkey creates a gap in literacy.

\section{Methodology}

\section{Design}

In this research, correlational survey model was utilized. "The survey research aims at collecting data to determine the specific characteristics of a group (Büyüköztürk et al., 2009, pp.16)". Karasar (1999, pp. 77) also "indicates that screening models are research approaches aiming to describe a situation that existed in the past or present".

\section{Participants}

221 undergraduate students studying in the social studies education of the faculty of education in a state university in 2016-2017 academic year participated in the study. The assessment tool was first implemented to 240 social studies undergraduate students and this number was reduced to 221 during the data extraction process. $128(57.9 \%)$ of the participants were female and $93(42.1 \%)$ were male. Of these students, $34(15.4 \%)$ were senior students, $56(25.3 \%)$ were sophomore students, $70(31.7 \%)$ were junior students and $61(27.6 \%)$ were senior students. While $18(8.1 \%)$ of the students did not utilize any maps, $114(51.6 \%)$ hardly ever utilized maps, 76 (14.4\%) utilized maps in moderate level, and $13(5.9 \%)$ utilized maps very frequently.

\section{Instrumentation}

To predict the level of map literacy of social studies undergraduate students, a map literacy scale: "Developing Valid and Reliable Map Literacy Scale" developed by Koç and Demir (2014) was made use of. The assessment tool of the research consists of two parts. The 
first part included variables such as class, gender, frequency of using maps, frequency of activities with maps, aim of using maps, the type of maps they used most and their level of interest in Geography as a discipline. The map literacy scale which is the second part of the tool contains five factors: map knowledge and skill test, studying with maps, reading and interpreting maps, drawing outline maps and using maps. The first of these factors is to measure the students' map knowledge and it has 23 items. The KR20 reliability coefficient of the test of map knowledge was .76. The map literacy scale is in the form of the five-point Likert scale and composed of four factors. Regarding the results of exploratory and confirmatory factor analysis conducted in the validity and reliability study, the scale consists of 4 dimensions. The scale consists of 24 items, 4 of which are related to being able to study with maps, 9 for reading and interpreting maps, 3 for drawing outline maps and 8 for using maps. Factor loads of the items on the scale ranged from .46 to .76. The correlation coefficients of the 24 items in the proficiency section of the Map Literacy Scale range between .51 and .75 . In the paired comparisons between the four factors of the scale, positive and moderate (.42-.68) relationships were explored and positive and strong relationships (.70, $.78, .80, .90)$ were determined in total.

\section{Data Analysis}

Firstly, the levels of undergraduate students were determined through exploring the average scores of the students' total scores from these 5 dimensions. A standardized maximum score (60) was determined for students from all dimensions. Then, multipliers were determined to calculate the minimum and maximum scores that can be obtained from each dimension according to this standardized score. Table 1 presents these multiplier values that will be used in determining map literacy levels of students.

Table 1. The values of map literacy scale

\begin{tabular}{llllll}
\hline Map literacy factors & Items & $\begin{array}{l}\text { Score } \\
\text { Range }\end{array}$ & Multiplier & $\begin{array}{l}\text { Min } \\
\text { Score }\end{array}$ & $\begin{array}{l}\text { Max } \\
\text { Score }\end{array}$ \\
\hline Knowledge and skill & 23 & $0-23$ & 2.608 & 0 & 60 \\
Study with maps & 4 & $4-20$ & 3 & 12 & 60 \\
Reading and interpreting maps & 9 & $9-45$ & 1.333 & 12 & 60 \\
Drawing outline maps & 3 & $3-15$ & 4 & 12 & 60 \\
Using maps & 8 & $8-40$ & 1.5 & 12 & 60 \\
\hline Map literacy score & 47 & $24-143$ & & 48 & 300 \\
\hline
\end{tabular}

Statistical analysis was performed through SPSS 24 program. Pearson Product Moment Correlation Coefficient (r) was utilized to calculate the relationships between variables. Besides, "the multiple linear regression analysis" technique was used so as to determine the regression levels of the independent variables (frequency of using maps, frequency of activity with maps and interest in Geography) to dependent variables. Standardized Beta $(\beta)$ coefficients and t-test results regarding their significance were taken into consideration in the interpretation of regression analyses. In data analysis, .05 significance level was taken as a basis. The assumption of normality and linearity for the data obtained from the study group is presented in the following graphs. 


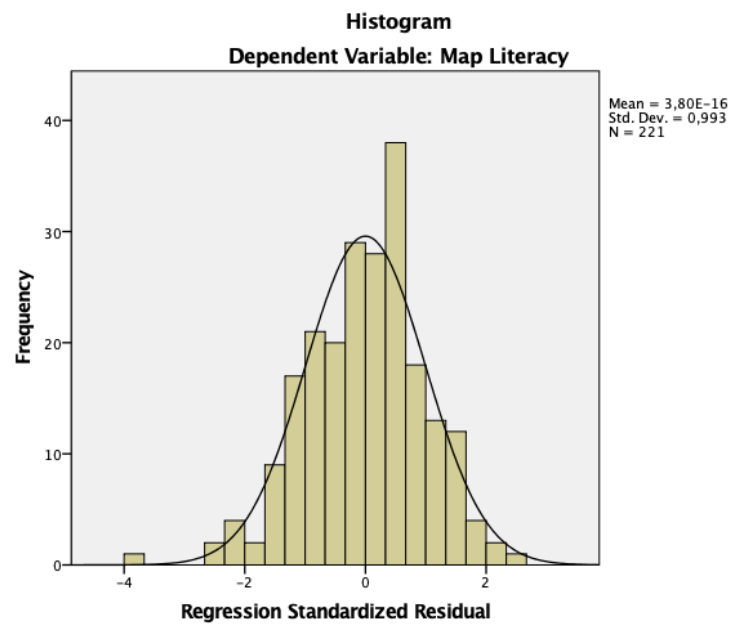

Figure 1. Assumption of normality regarding map literacy scores of social studies undergraduate students.

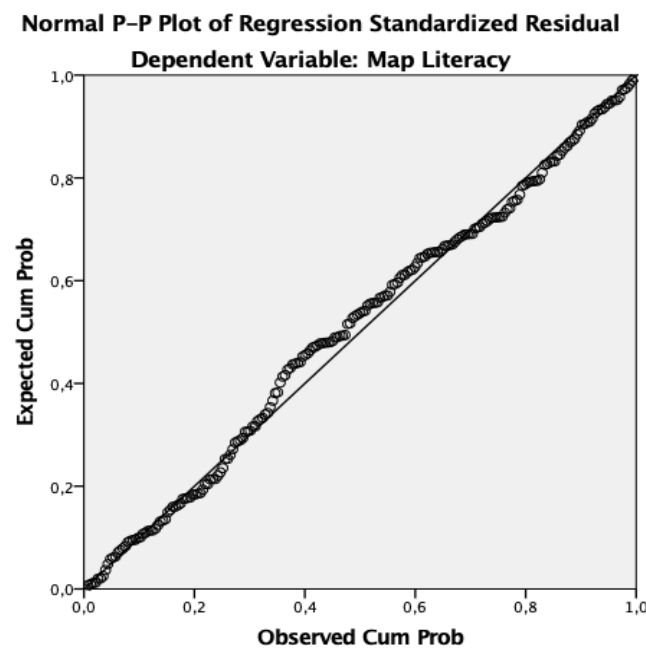

Figure 2. Assumption of linearity regarding map literacy scores of social studies undergraduate students.

The results of Figures 1 and 2 indicate that the social undergraduate students' map literacy scores show a multivariate normal distribution and are linear. Hence it satisfies the assumptions of multiple linear regression analysis.

\section{Findings}

\section{Findings and Discussions on the Determination of Map Literacy Levels of Social Studies Undergraduate Students}

In the research problem, it was investigated whether there was a significant relationship between the social literacy students' map literacy, the frequency of using maps, the frequency of activity with maps and the level of interest in Geography. Multiple linear regression analysis was conducted to reveal the relationship. The results are presented in Table 2.

Table 2. The results of multiple linear regression analysis of map literacy scale

\begin{tabular}{llcccccc}
\hline & $\mathbf{B}$ & $\begin{array}{l}\text { Standard } \\
\text { Error }\end{array}$ & $\boldsymbol{\beta}$ & $\mathbf{t}$ & $\mathbf{p}$ & $\begin{array}{l}\text { Zero } \\
\text { order } \mathbf{~ r}\end{array}$ & Partial $\mathbf{r}$ \\
\hline Invariant & 43,083 & 4,927 & & 8,744 &, 000 & & \\
\hline $\begin{array}{l}\text { The frequency of using } \\
\text { maps }\end{array}$ & 3,399 & 1,562 &, 137 & 2,176 &, 031 &, 301 &, 146 \\
$\begin{array}{l}\text { The frequency of activity } \\
\text { with maps }\end{array}$ & 2,884 & 1,395 &, 125 & 2,068 &, 040 &, 245 &, 139 \\
$\begin{array}{l}\text { The level of interest in } \\
\text { geography }\end{array}$ & 9,544 & 1,538 &, 399 & 6,205 &, 000 &, 482 &, 388 \\
\hline $\mathrm{R}=0.514$ & $\mathrm{R}^{2}=0.264$ & \multicolumn{2}{c}{$\mathrm{F}_{(3-217)}=25.945 \mathrm{p}=.000$} & & & & \\
\hline
\end{tabular}

Regarding the correlations and partial correlations between the predictor variables and dependent variables, the results of the regression analysis in Table 1 indicated that there is a positive and moderate correlation $(\mathrm{r}=.30)$ between the social studies undergraduate students' level of map literacy and the frequency of using maps. When the other variables were checked, the correlation coefficient between the two variables was calculated as $r=.15$. There are a positive and weak relationship between the social studies undergraduate students' map 
literacy level and frequency of activity with maps $(\mathrm{r}=.25)$. As for the other variables, the correlation between the two variables was calculated as .14. There is a positive and moderate relationship $(\mathrm{r}=.48)$ between the social studies undergraduate students' map literacy level and the level of interest in Geography. However, when the other variables were checked, the correlation between the two variables was calculated as .39 as a moderate level. Additionally, there is a moderate and significant relationship $\left[R=0.51 ; R^{2}=0.27 ; p<.05\right]$. Between the social studies undergraduate students' frequency of using maps, the frequency of activities with maps and the level of interest in Geography and map literacy together, these three variables account for approximately $26 \%$ of the total variance.

Regarding the standardized regression coefficient $(\beta)$, the relative importance order of the predictive variables on the level of map literacy is the level of interest in Geography, the frequency of using maps and the frequency of activity with maps. As for the t-test results to the significance of the regression coefficients, it was explored that the frequency of using maps, the frequency of activity with maps and the level of interest in Geography were significant predictors of the social literacy students' map literacy levels. The results of the regression analysis with regard to the regression equation for determining the map literacy levels of social studies undergraduate students are presented below.

The Map Literacy=43.083+3.399FUM+2.884FAWM+9.544LIG.

\section{Results, Discussion, and Implications}

This study had an attempt to determine the level of map literacy of social studies undergraduate students. For this purpose, map literacy score obtained from the map competence and map knowledge-skill scales applied to the study group was the dependent variable of the research whereas frequency of using maps, frequency of activity with maps, and level of interest in Geography were independent variables of the research. The results obtained from the research conducted in the correlational survey model are as follows.

The results of the research regarding correlations between the predictor variables and dependent variables exhibited that there is a positive and moderate level relationship between social studies undergraduate students' map literacy levels and frequency of using maps and variables of interest in Geography. Yet it was figured out that there is a positive and weak relationship between social literacy students' map literacy levels and frequency of activity with maps.

The partial correlation coefficients calculated by examining the other variables between the predictive variables and dependent variables showed that there was a positive and weak relationship between the social studies undergraduate students' map literacy levels, and the frequency of using maps and the frequency of activities with maps. On the other hand, it was found out that there were a positive and moderate level relationship between the social studies undergraduate students' map literacy levels and the level of interest in Geography.

The results of the study also demonstrated that the social studies undergraduate students' frequency of using maps, the frequency of activity with maps and the level of interest in the Geography together with map literacy possessed a moderate and significant relationship. Thusly the results of the research concluded that the map skills of social studies undergraduate students are an important predictor of map literacy.

In their studies on determining map competencies of Geography students, Aksoy and Koç 
(2017) found out that there was a positive and moderate relationship between the undergraduate students' level of map competencies, and their ability to study with maps and drawing outline maps. They were also pinpointed that there was a positive and high-level relationship between students' map competence levels, and variables of reading and interpretation of map and map usage. Moreover, the results of partial correlations also showed that there was a positive and high-level relationship between the students' levels of map competencies, and the ability to study with maps, reading and interpretation of maps, drawing outline maps and map usage.

In their study, Aksoy and Ablak (2017) found that there was a positive and moderate relationship between the social studies undergraduate students' map literacy skills, and their ability to study with maps, map reading, drawing outline map and map competences. The results of partial correlations between the predictor variables and the dependent variable also displayed that there was a positive and moderate relationship between the students' map literacy skills, and their ability to study with maps and reading and interpretation of maps. However, a positive and weak relationship between the students' map literacy levels and drawing outline maps and map competences was detected. Along with that there was a significant and moderate relationship between the variables of students' ability to study with maps, to reading and interpretation of maps, to draw outline maps, and map usage and the variable of map literacy level.

In their study, Aksoy and Ablak (2017) found that there were a positive and moderate relationship between the social studies undergraduate students' map literacy levels, and their ability to study with maps, to map reading, to draw outline map and map usage. The results of partial correlations between the predictive variables and the dependent variable also showed that there was a positive and moderate relationship between the students' map literacy levels, and their ability to study with maps and to reading and interpretation of maps. Howbeit, a positive and weak relationship between the students' map literacy levels and the variables of drawing outline maps and maps usage was spotted. Correspondingly, a moderate and significant relationship between the students' level of map literacy, and the variables of studying with maps, reading and interpretation of maps, drawing outline maps and maps usages was diagnosed.

The results of the study indicate that map skills are important components of map literacy. These results are in parallel to the studies of Sönmez (2010), Aksoy (2013), Koç and Karatekin (2015), Koç and Çifçi (2016), and Koç, Aksoy and Çifçi (2017). The results of Aksoy's (2013) study found out that the variables of gender, having an atlas, department and field of study were effective on the 8 map skills scores of undergraduate students. Also, the map skill levels of Geography and social studies undergraduate students and students studying in verbal and numerical fields were found to be higher than other students. Koç, Aksoy and Çifçi (2017) figured out that the undergraduate students' levels of map literacy (knowledgeskill and competence) shows a significant difference with respect to the variables of the gender, faculty, frequency of using maps, level of participation in various activities in natural environment, aim of using maps in daily life and interest in Geography lesson. Those differences are in favor of male students, the students studying at the faculty of medicine, the faculty of dentistry as well as students who utilize the map more often, who participate in activities more and who attend Geography courses.

The results of the research revealed that the frequency of using maps, the frequency of activity with maps and the level of interest in Geography are important and significant 
predictors of map literacy of social studies undergraduate students. This result is similar to that of Aksoy and Ablak (2017), Aksoy and Koç (2017).

Similar to the above result, Aksoy and Ablak (2017) found out that there was a moderate and significant difference between the social studies undergraduate students' level of map literacy, and the ability to study with maps, to the reading and interpretation of maps, to draw outline maps, to map usage. Aksoy and Koç (2017) figured out that there was a very high level and significant relationship between the Geography undergraduate students' level of map competencies, and the ability to study with maps, to the reading and interpretation of maps, to draw outline maps and to the map usage. Koç and Karatekin (2015) underlined that the social studies prospective teachers' levels of map knowledge were close to the lower level, and that their ability to study with maps, to the reading and interpretation of maps, to draw outline maps and to map usages were at the intermediate level. The results of Koç and Çifçi (2016) presented that prospective primary school prospective teachers had a moderate level of map literacy. The results of the effect of gender variable on the map literacy of primary school prospective teachers indicated a significant difference in favor of male teachers in the dimensions of drawing maps and map usage. The results of the effect of the frequency of using map variable on the map literacy of primary school prospective teachers showed a significant difference in favor of prospective teachers who had a higher frequency of reading and interpreting maps, drawing maps and using map in all dimensions of map literacy scores. Apart from this, the results of the effect of the interest in Geography variable on the map literacy of primary school prospective teachers showed a significant difference in favor of prospective teachers who were more interested in Geography. The study of Erol (2017) announced that the seventh-grade students had a moderate level of map literacy. The geographical knowledge of students seemed to develop not as desired due to a lack of relevant practice and absence of interpretation of the geographical information. Scarcity of sufficient number of activities in map literacy in social studies textbooks was thought to have a negative effect on the development of this skill.

\section{Implications}

The results of the research manifested that the frequency of using maps, the frequency of activity with maps and the level of interest in Geography were important and significant predictors of social studies undergraduate students' levels of map literacy. For this reason, social studies undergraduate curriculums need to concentrate on lectures and practices that will help develop map knowledge/skills/competencies in order to use maps, which is one of the most important expression methods of the subjects of the Geography discipline, alongside being an effective teaching tool. What is more, it is suggested that the lectures for map knowledge are suggested to be supported by technological materials (digital maps and applications) to increase the interest of students.

\section{Acknowledgement}

This study was presented as an oral presentation at the Academic Conference on Education, Teaching and E-learning 2017 in Prague

\section{References}

Aksoy, B. (2013) Investigation of Mapping Skills Of Pre-Service Teachers As Regards To Various Parameters. Educational Research and Reviews, 8(4):134-143. 
Aksoy, B., Kılıçoğlu, G. \& Ablak, S. (2015). 11-14 Yaş Grubundaki Öğrencilerin Harita Beceri Düzeyleri İle Matematik Başarıları Arasındaki İlişki [The Relation Of 11-14 Years Old Students Map Skills And Their Achievement Levels In Mathematics]. Journal of World of Turks, 7(2):59-71.

Aksoy, B. \& Ablak, S. (2017). Exploring map literacy of social studies undergraduate students. Academic Conference on Education, Teaching and E-learning 11-14 August, Prague, 657.

Aksoy, B. \& Koç. H. (2017). Coğrafya lisans öğrencilerinin harita yeterlik düzeylerinin yordanmasl [Exploring map proficiency levels of undergraduate geography students]. 7th International Congress of Research in Education, 27-29 April, Çanakkale, 337.

Buckley, A. R., Muehrcke, P. C. \& Muehrcke, J. O. (2011). Map use: Reading, analysis and interpretation. Redlands, CA: Esri Press.

Büyüköztürk, Ş., Çakmak, K. E., Akgül, E. Ö., Karadeniz, Ş. \& Demirel, F. (2009). Bilimsel araştırma yöntemleri [Scientific research methods]. Ankara: Pegem Academy.

Carbonell Carrera, C., Avarvarei, B. V., Chelariu, E. L., Draghia, L.\& Avarvarei, S. C. (2017). Map-reading skill development with 3d technologies. Journal of Geography, 116 (5), 197-205.

Carswell, R. J. B. (1971). The Role of the user in the map communication process: children's abilities in topographic map reading. Cartographica. The International Journal for Geographic Information and Geovisualization, 8(2), 40-45.

Catling, S. J. (1998). Geographical work in primary and middle schools. Sheffield: Geographical Association.

Clarke, D. (2003). Are you functionally map literate?, Proceedings of the 21 st International Cartographic Conference (ICC). South Africa: Durban. 10-16 August, 713-719.

Demiralp, N. (2006). Coğrafya eğitiminde harita ve küre kullanma becerileri [Use of maps and globes in geography education]. Gazi University Journal of Gazi Educational Faculty, 4(3), 323-343.

Erol, H. (2017). Ortaokul öğrencilerinin harita okuryazarlık becerileri üzerine bir değerlendirme [An evaluation on secondary school students' map literacy skills]. Anadolu Journal of Educational Sciences International, 7(3), 425-457.

Fouberg, H. E., Murphy, A. B. \& Blij, H.J. (2012). Human geography. USA: Wiley Plus.

Gerber, R. \& Wilson, P. (1989). Using maps well in the geography classroom. In J. Fien., R. Gerber \& P. Wilson (Ed.), The geography teacher's guide to the classroom. Melbourne: Macmillan.

Gilmartin, P. P. \& Patton, J. C. (1984). Comparing the sexes on spatial abilities: map-use skills. Annals of the Association of American Geographers, 74(4), 605-619.

Golledge, R. G., Marsh, M. \& Battersby, S. (2008). Matching geospatial concepts with geographic educational needs. Geographical Research, 46(1), 85-98.

Gökçe, N. (2015). Social studies in improving students' map skill: Teachers' opinions. Educational Sciences: Theory \& Practice, 15(5), 1345-1362.

Harita Genel Müdürlüğ̈̈ [General Directorate of Mapping]. https://www.harita.gov.tr/images/egitim/87245f4b1d0d12c.pdf (Erişim Tarihi 02.05.2019).

Head, C. G. (1984). The map as natural language: A paradigm for understanding, Cartographica, 21(1), 1-25.

Hirsch, P. L. \& Sandberg, E. H. (2013). Development of map construction skills in childhood. Journal of Cognition and Development, 14(3), 397-423.

Hsu, H.P., Tsai, B.W. \& Chen, C.M. (2018).Teaching topographic map skills and geomorphology concepts with google earth in a one-computer classroom. Journal of Geography, 117(1), 29-39. 
Jongwon, L. \& Bednarz R. (2012). Components of spatial thinking: evidence from a spatial thinking ability test. Journal of Geography, 111(1), 15-26.

Karasar, N. (1999). Bilimsel araştırma yöntemi [Scientific research methods]. Ankara: Nobel Publisher.

Kızılçaoğlu, A. (2007). Harita becerilerine pedogojik bir bakış [A pedagogical overview of map skills]. The Journal of Institute of Social Sciences, 18, 341-358.

Krygier, J. \& Wood, D. (2005). Making maps. New York: The Guilford Press.

Koç H. (2008). Coğrafya öğretim programındaki kazanımların öğrencilerin harita beceri düzeyleri üzerine etkisi [The effect of the gains at the program of geography teaching on skill levels of mapping of the students]. (PhD Thesis), Gazi University Institute of Educational Sciences.

Koç, H. (2010). Coğrafya eğitiminde harita algısı ve kullanımı [Map perception and usage in geography education]. National Education, 87, 146-158.

Koç H. \& Demir S. B. (2014). Developing valid and reliable map literacy scale. Review of International Geographical Education, 4(2), 120-136.

Koç H. \& Karatekin K. (2015). Sosyal bilgiler öğretmen adaylarının harita okuryazarlık düzeylerinin çeşitli değiş̧enler açısından incelenmesi [An examination of map literacy levels of prospective social studies teachers in terms of various variables]. $4^{\text {th }}$ USBES. Bolu.

Koç H. \& Çifçi T. (2016). Sınıf öğretmeni adaylarının harita okuryazarlık düzeylerinin çeşitli değişkenler açısından incelenmesi [An investigation into map literacy levels of elementary school teacher candidates based on various variables]. Marmara Geographical Review, 34, 9-20.

Koç, H., Aksoy, B. \& Çifçi, T. (2017). Farklı lisans programlardaki öğrencilerin harita okuryazarlık düzeylerinin çeşitli değişkenler açısından incelenmesi: Cumhuriyet Üniversitesi Örneği [An examination of map literacy levels of students from various undergraduate programmes according to several variables: Cumhuriyet university sample]. Erzincan University Journal of Education Faculty, 31(1), 301-321.

Koç, H. (2017). Coğrafya öğretimin haritalar ve atlasların kullanımı [Use of maps and atlases at geography teaching], A. Sever (Ed) Coğrafya öğretim teknolojileri ve materyal tasarımı içinde (pp.115-141), Ankara: Pegem Academy.

Liben, L. \& Downs, R. (1989). Understanding maps as symbols: the development of map concepts in children. New York: Academic Press.

MacEachren, M. (2004). How maps work. New York: The Guilford Press.

Mcbride, B. (2011). Essential elements of ecological literacy and the pathways to achieve it: perspectives of ecologists (Unpublished Doctoral Dissertation), The University of Montana, Missoula.

McClure, R. W. (1992). A conceptual model for map skills curriculum development based upon a cognitive field theory philosophy (Unpublished Doctoral Dissertation), Oklahoma State University, Oklahoma.

Olson, J. M. (1976). A coordinated approach to map communication improvement. The American Cartographer, 3(2), 151-159.

Rautenbach, V. Coetzee, S. \& Çöltekin, A. (2017). Development and evaluation of a specialized task taxonomy for spatial planning - A map literacy experiment with topographic maps. ISPRS Journal of Photogrammetry and Remote Sensing, 127, 1626.

Schultz, R.B., Kerski, JJ. \& Peterson, T. C. (2008). The use of virtual globes as a spatial teaching tool with suggestions for metadata standards. Journal of Geography, 107(1), 27-34. 
Sönmez, Ö.F. (2010). Sosyal Bilgiler Öğretiminde Harita Becerileri [Map Skills in Primary School Social Studies Education]. (PhD Thesis), Gazi University Institute of Educational Sciences.

Sönmez, Ö.F. \& Aksoy, B. (2012). İlköğretim ikinci kademe öğrencilerinin harita beceri düzeylerinin belirlenmesi [Determination of primary education secondary stage students' map skill levels]. Turkish Studies-International Periodical for the Languages, Literature and History of Turkish or Turkic, 7(1), 1905-1924.

Tümertekin, E. \& Özgüç, N. (2000). Coğrafya, Geçmiş Kavramlar Coğrafyacılar [Geography, Past Concepts Geographers]. İstanbul: Çantay Publisher.

Ünlü, M., Üçışık, S. \& Özey, R. (2002). Coğrafya Eğitim ve Öğretiminde Haritaların Önemi [The Importance of Maps in Geography Education and Training]. Marmara Geographical Review, 5, 9-25.

Weeden, P. (1997). Learning through maps. D. Tilbury \& M. Williams (Eds.), Teaching and learning geography, In (pp. 168-179). London: Routledge.

White S. H. (1995). An examination of the effects of mixed-age grouping on learning map reading skills (Unpublished Dissertation), Texas: A\&M University.

Wiegand, P. (2006). Learning and teaching with maps. New York: Routledge.

Wood, D. (1992). The power of maps. New York: The Guilford. 